\title{
P148 The Administration of Green Tea Extract Improves Hemodynamic Parameters, Arterial Stiffness and Renal Function in Patients with Diabetic Nephropathy
}

\author{
Marycruz Barocio*, Fernando Grover, Mayra Jiménez, Mariana Larios, Patricia Quezada, Jhonatan Trujillo,
} Ernesto Cardona, David Cardona, Carlos Ramos

University of Guadalajara, Guadalajara, Mexico

\section{ABSTRACT}

Purpose/Background/Objectives: Type 2 Diabetes Mellitus (T2DM) is a disease characterized by macro and microvascular complications, particularly, coronary heart disease, cerebrovascular disease and nephropathy [1-4]. The green tea extract has shown an anti-inflammatory effect (2), so this nutraceutical could be an alternative adjuvant in the treatment of the patient with diabetic nephropathy (DN) [5-7]. To evaluate the effect of the administration of green tea extract on hemodynamic, arterial stiffness, metabolic and renal function parameters in patients with DN.

Design and Methods: It was a randomized, double-blind study performed in 28 patients with DN, 14 assigned to placebo and 14 green tea extract, $400 \mathrm{mg}$ every 12 hours for 12 weeks. Hemodynamic and arterial stiffness parameters were determined with HEM-9000AI, VP1000 Omron and metabolic parameters and renal function with Erba XL-100 equipment.

Results: The group under green tea extract treatment had significant decrease in the systolic blood pressure ( $\mathrm{mmHg}$ ) compared to those under placebo $(-4.3 \pm 12.7$ vs $5.4 \pm 12.2)$, central pressure $(\mathrm{mmHg})(-6.0 \pm 13.4 \mathrm{vs} 9.1 \pm 14.4)$, pulse pressure $(\mathrm{mmHg})$ $(-3.5 \pm 6.6$ vs $3.3 \pm 6.4)$, triglycerides $(\mathrm{mg} / \mathrm{dl})(-16.4 \pm 46.7$ vs $30.3 \pm 35.9)$, creatinine $(-1.3 \pm 0.2$ vs $0.1 \pm 0.1)$ and GFR $\left(\mathrm{ml} / \mathrm{min} / 1.73 \mathrm{~m}^{2}\right)[8](6.2 \pm 5.9 \mathrm{vs}-7.7 \pm 10.9)$.

Conclusion: The administration of green tea extract improves hemodynamic parameters, metabolic parameters and renal function in patients with DM2 and chronic kidney disease.

\section{REFERENCES}

[1] Chen L, Magliano DJ, Zimmet PZ. The worldwide epidemiology of type 2 diabetes mellitus-present and future perspectives. Nat Rev Endocrinol 2011;8:228-36.

[2] Rosales-Gómez RC, López-Jiménez JJ, Núñez-Reveles NY, González-Santiago AE, Ramírez-García SA. Nefropatía por diabetes mellitus tipo 2: un rasgo multifactorial con umbral y su mapa mórbido cromosómico. Rev Med Inst Mex Seguro Soc 2010;48:521-30.

[3] Han Cho N, Kirigia J, Mbanya JC, Ogurstova K, Guariguata L, Rathmann W, et al. Diabetes atlas de la FID. $8^{a}$ edición. 2017.

[4] Heerspink HJ, Perkins BA, Fitchett DH, Husain M, Cherney DZ. Sodium glucose cotransporter 2 inhibitors in the treatment of diabetes mellitus: cardiovascular and kidney effects, potential mechanisms, and clinical applications. Circulation 2016;134:752-72

[5] Adamopoulos C, Mihailidou C, Grivaki C, Papavassiliou KA, Kiaris H, Piperi C, et al. Systemic effects of AGEs in ER stress induction in vivo. Glycoconj J 2016;33:537-44.

[6] Tuttle KR, Bruton JL, Perusek MC, Lancaster JL, Kopp DT, DeFronzo RA. Effect of strict glycemic control on renal hemodynamic response to amino acids and renal enlargement in insulin-dependent diabetes mellitus. N Engl J Med 1991;324:1626-32.

[7] Yang CS, Chen L, Lee MJ, Balentine D, Kuo MC, Schantz SP. Blood and urine levels of tea catechins after ingestion of different amounts of green tea by human volunteers. Cancer Epidemiol Biomarkers Prev 1998;7:351-4.

[8] Levey AS, Stevens LA, Schmid CH, Zhang YL, Castro AF, Feldman HI, et al. A new equation to estimate glomerular filtration rate. Ann Intern Med 2009;150:604-12.

(c) 2019 Association for Research into Arterial Structure and Physiology. Publishing services by Atlantis Press International B.V. This is an open access article distributed under the CC BY-NC 4.0 license (http://creativecommons.org/licenses/by-nc/4.0/). 